\title{
PENGARUH PROFITABILITAS DAN PERTUMBUHAN PERUSAHAAN TERHADAP NILAI PERUSAHAAN SUB SEKTOR TELEKOMUNIKASI
}

\author{
Sandhi Mandala Putra \\ Fakultas Ekonomi Perbanas Institute \\ sandhi.mandala@gmail.com
}

\begin{abstract}
ABSTRAK
Perusahaan telekomunikasi dianggap menghasilkan laba yang tinggi karena kenaikan konsumsi rumah tangga masyarakat Indonesia yang cukup konsisten. Ada dugaan bahwa Return On Assets (ROA) dan Pertumbuhan Perusahaan (Growth) yang menjadi salah satu faktor penyebabnya. Penelitian ini dilakukan pada perusahaan sub sektor telekomunikasi yang terdaftar di Bursa Efek Indonesia (BEI). Populasi perusahaan yang dipilih dalam penelitian ini menghasilkan profit dan menerbitkan laporan keuangan selama kurun waktu 2015 - 2019. Sampel yang digunakan adalah purposive sampling. Metode penelitian kuantitatif dengan analisis data yang digunakan uji t, uji $\mathrm{F}$, regresi linier berganda dan koefisien determinasi. Kesimpulan penelitiannya adalah ditemukan bahwa ROA tidak berpengaruh dan signifikan terhadap nilai perusahaan, sedangkan pertumbuhan perusahaan berpengaruh positif dan signifikan terhadap nilai perusahaan. Perusahaan harus memperhatikan pertumbuhaan perusahaan dalam bentuk pertumbuhan aset untuk mencapai nilai perusahaan yang optimal.
\end{abstract}

Kata Kunci : Pertumbuhan Perusahaan, Profitabilitas, Nilai Perusahaan dan Telekomunikasi

\section{ABSTRACT}

Telecommunications companies are considered to generate high profits because of the consistent increase in Indonesian household consumption. There are allegations that Return On Assets (ROA) and Company Growth (Growth) are one of the contributing factors. This research was conducted on telecommunication sub-sector companies listed on the Indonesia Stock Exchange (IDX). The population of companies selected in this study generate profits and publish financial reports for the period 2015 - 2019. The sample used is purposive sampling. Quantitative research method with data analysis used t test, F test, multiple linear regression and $R$ square. The conclusion of the research is that ROA has no significant and positive effect on firm value, meanwhile firm growth has a positive and significant effect on firm value. Companies must pay attention to company growth in the form of asset growth to achieve optimal company value

Keywords: Company Growth, Profitability, Company Value and Telecommunication

Diterima: 12 September 2021; Direvisi: 27 September 2021; Diterbitkan: Oktober 2021

PENDAHULUAN
Perusahaan pada umumnya memiliki tujuan untuk menghasilkan laba sebanyak- 
banyaknya dengan sumber daya yang dimiliki. Dengan sumber daya yang ada dan terbatas, maka perusahaan harus menyusun strategi agar dapat menghasilkan laba sambil tetap menjaga keberlangsungan perusahaan. Apabila perusahaan tersebut dapat menghasilkan laba yang konsisten dalam jangka waktu yang cukup lama, maka dapat dikatakan perusahaan tersebut sukses dalam memaksimalkan sumber daya yang dimiliki. Keuntungan yang konsisten lebih sulit diperoleh karena setiap tahunnya terdapat berbagai masalah yang menganggu keberlangsungan perusahaan seperti tingkat perekonomian suatu negara, politik, sumber bahan baku yang berkualitas, dan hal-hal lainnya.

Ketika perusahaan sudah cukup matang dan membutuhkan sumber pendanaan yang baru, salah satu langkah yang ditempuh adalah menjual saham perusahaan melalui pasar modal Bursa Efek Indonesia (BEI). Di pasar modal, perusahaan bisa mendapatkan pendanaan untuk melakukan ekspansi, merestrukturisasi utang, maupun kegiatan lainnya. Untuk menarik calon investor, perusahaan harus memiliki kinerja keuangan yang baik yang ditunjukkan melalui laporan keuangan.

Nilai perusahaan merupakan salah satu hal yang dinilai oleh calon investor. Semakin baik nilai perusahaan, semakin menarik pula perusahaan tersebut di mata calon investor. Dengan terus meningkatkan kinerja perusahaan, harga saham perusahaan akan naik. Nilai perusahaan dipengaruhi oleh unsur internal dan unsur eksternal. Unsur internal dari keadaan perusahaan itu sendiri seperti tingkat profitabilitas, pertumbuhan aset (growth), good corporate governance (GCG), pengelolaan utang, dan unsur internal lainnya. Dari sisi unsur eksternal, terdapat faktor yang tidak dapat dikendalikan perusahaan seperti pertumbuhan ekonomi, tingkat inflasi, dan unsur eksternal lainnya. Manajer keuangan perusahaan selaku pengelola keuangan harus memerhatikan hal-hal tersebut dengan seksama agar tidak merugikan perusahaan.

Terdapat beberapa perbedaan penelitian tentang faktor-faktor yang mempengaruhi nilai perusahaan yang telah dilakukan sebelumnya. Dalam penelitian Husna dan Satria (2019), Return On Assets (ROA) memiliki pengaruh positif dan signifikan terhadap nilai perusahaan. Hal yang sama ditemukan pula pada penelitian oleh Putri dan Ukriwiyati (2016) serta Henviani dan Sanjaya (2020). Namun hal yang berbeda ditemukan pada penelitian Harsiatun dan Hidayat (2019) dimana ROA berpengaruh negatif dan tidak signifikan, yang didukung oleh penelitian oleh Putranto (2018:96) dan Oktrima (2017).

Dari sisi pertumbuhan perusahaan (growth), penelitian yang dilakukan oleh Meidiawati (2016) menunjukkan pertumbuhan perusahaan tidak berpengaruh terhadap nilai perusahaan. Kesimpulan serupa didukung oleh penelitian Yuslirizal (2017) dan Paminto, Setyadi, dan Sinaga (2016). Namun penelitian yang dilakukan oleh dan Perwira dam Wiksuana (2018) menunjukkan bahwa pertumbuhan perusahaan berpengaruh positif dan signifikan terhadap nilai perusahaan. Kesimpulan tersebut didukung oleh penelitian Suryandani (2018) dan Syahrial, Yuliansyah, dan Sudrajat (2020).

Objek pada penelitian ini adalah perusahaan sub sektor telekomunikasi yang terdiri dari 18 emiten dengan fenomena murahnya perangkat 
smartphone, tingkat perekonomian Indonesia yang membaik, dan kemudahan membeli paket internet dengan harga yang terjangkau membuat masyarakat Indonesia dapat mengakses internet di mana saja. Selain hal-hal tersebut, konsumsi rumah tangga Indonesia untuk keperluan komunikasi mengalami peningkatan selama kurun waktu 2015 2019. Hal ini tercermin dalam laporan Badan Pusat Statistik Tahun 2020 mengenai rata-rata konsumsi rumah tangga Indonesia untuk telekomunikasi dalam kurun waktu 2015 sampai dengan 2019.

\begin{tabular}{|c|c|}
\hline Tahun & $\begin{array}{c}\text { Rata-rata konsumsi rumah tangga untuk } \\
\text { telekomunikasi (Rp) }\end{array}$ \\
\hline 2015 & 121.373 \\
\hline 2016 & 128.492 \\
\hline 2017 & 130.068 \\
\hline 2018 & 147.657 \\
\hline 2019 & 151.883 \\
\hline
\end{tabular}

Sumber: Laporan Badan Pusat Statistik, 2021

Tujuan dari penelitian ini adalah untuk mengetahui apakah profitabilitas dan pertumbuhan perusahaan mempengaruhi nilai perusahaan.

\section{KAJIAN TEORETIK}

\section{Nilai Perusahaan}

Nilai perusahaan menurut Sugeng (2017) didefinisikan sebagai nilai kekayaan bersih dari pemilik perusahaan. Semakin tinggi nilai perusahaan, semakin tinggi nilai kekayaan pemilik perusahaan tersebut. Pada penelitian ini, peneliti menggunakan nilai buku perusahaan (price book value) sebagai konsep nilai perusahaan.

Menutur Prihadi (2017), rumus price book value (PBV) adalah sebagai berikut:

$$
P B V=\frac{\text { harga saham per lembar }}{\text { nilai buku per lembar saham }}
$$

\section{Profitabilitas}

Profitabilitas adalah kemampuan suatu perusahaan untuk menghasilkan laba (Prihadi, 2019). Investor dan analis akan memperhatikan profitabilitas suatu perusahaan sebagai daya tarik utama.

Dalam penelitian ini, peneliti menggunakan return on assets sebagai alat ukur rasio profitabilitas. Return on Assets (ROA) mengukur tingkat laba terhadap asset yang digunakan dalam menghasilkan laba tersebut.

Menurut Hery (2016:21), rumus ROA adalah sebagai berikut

Return On Assets $=\frac{\text { Laba bersih setelah pajak }}{\text { total asset }}$

\section{Pertumbuhan Perusahaan (Growth)}

Menurut Perwira dan Wiksuana (2018), Pertumbuhan perusahaan (growth) dinyatakan dengan perubahan (penurunan atau peningkatan) total asset saat ini dibandingkan dengan total asset masa lalu.

Rumus pertumbuhan perusahaan adalah sebagai berikut:

$$
\text { Pertumbuhan perusahaan }=\frac{T A_{t}-T A_{t-1}}{T A_{t-1}}
$$

\section{Kerangka Penelitian}




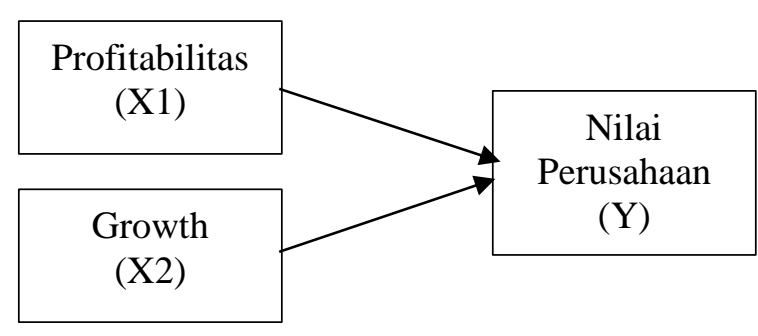

Gambar 1. Kerangka Penelitian

Sumber: Suryandani (2018), Putri dan Ukhriyawati (2016)

\section{Hipotesis Penelitian}

\section{Pengaruh Profitabilitas Terhadap Nilai Perusahaan}

Profitabilitas merupakan salah satu unsur yang dapat mempengaruhi nilai perusahaan. Profit perusahaan merupakan gambaran dari kemampuan perusahaan untuk menghasilkan laba dari proses bisnisnya untuk keberlangsungan perusahaan. (Henviani dan Sanjaya, 2020 dalam Manoppo dan Arie, 2016) (Hidayat et al., 2021).

\section{Profitabilitas dapat dihitung dengan ROA (return on assets) yang mencerminkan penggunaan aset untuk menghasilkan laba. Semakin tingginya profitabilitas perusahaan juga akan meningkatkan laba per lembar saham (EPS atau earning per share) perusahaan. Adanya peningkatan EPS akan membuat investor tertarik untuk menanamkan modalnya dengan membeli saham perusahaan. \\ $\mathrm{H}_{01}$ : Profitabilitas mempengaruhi nilai perusahaan sub sektor telekomunikasi.}

\section{Pengaruh Pertumbuhan Perusahaan Terhadap Nilai Perusahaan}

Pertumbuhan perusahaan merupakan salah satu unsur yang dapat mempengaruhi nilai perusahaan.
Pertumbuhan perusahaan sangat diharapkan oleh pihak internal maupun pihak eksternal,karena pertumbuhan perusahaan yang baik dapat memberikan sinyal positif terhadapperkembangan perusahaan. Perusahaan yang memiliki pertumbuhan total aktiva yang besar akan lebih mudah untuk mendapatkan perhatian dari pihak investor maupun kreditor karena mencerminkan perusahaan tersebut mampu menghasilkan laba yang dimanfaatkan untuk penambahan jumlah aktiva yang kemudian dapat meningkatkan nilai perusahaan (Meidiawati, 2016).

$\mathrm{H}_{\mathrm{o} 2}$ : Pertumbuhan perusahaan mempengaruhi nilai perusahaan.

\section{METODE PENELITIAN}

Metode penelitian ini merupakan penelitian kuantitatif dengan analisis regresi linier berganda. Pengolahan data menggunakan perangkat lunak Eviews versi 9. Data yang digunakan dalam penelitian ini adalah data sekunder berupa laporan keuangan_tahunan (financial report) perusahaan yang diambil dari situs resmi Bursa Efek Indonesia, yaitu www.idx.co.id. Populasi yang digunakan dalam penelitian ini adalah perusahaan sub sektor telekomunikasi yang terdaftar di Bursa Efek Indonesia (BEI) tahun 20152019 sebanyak 18 perusahaan. Kriteria sampel ditentukan dengan purposive sampling terdiri dari perusahaan sub sektor telekomunikasi yang terdaftar di BEI 2015 - 2019; perusahaan sub sektor telekomunikasi yang tidak mempublikasikan laporan keuangan secara berturut-turut selama 2015 - 2019; perusahaan sub sektor telekomunikasi yang mengalami kerugian selama 2015 2019.dari kriteria tersebut didapat sampel sebanyak 30 sampel data perusahaan 


\section{HASIL PENELITIAN PEMBAHASAN}

DAN

Berdasarkan kriteria penentuan sampel yang telah dibahas pada bab sebelumnya, sampel diperoleh dengan rincian sebagai berikut:

Tabel 2. Kriteria Penentuan Sampel

\begin{tabular}{|c|c|}
\hline Kriteria Sampel & Jumlah \\
\hline $\begin{array}{l}\text { Perusahaan sub } \quad \text { sektor } \\
\text { telekomunikasi yang terdaftar di BEI } \\
2015-2019\end{array}$ & 18 \\
\hline $\begin{array}{lcr}\text { Perusahaan } & \text { sub } & \text { sektor } \\
\text { telekomunikasi yang } & \text { tidak } \\
\text { mempublikasikan laporan keuangan } \\
\text { secara berturut-turut selama } \\
2015 \text { - } \\
2019\end{array}$ & (10) \\
\hline $\begin{array}{lcr}\text { perusahaan } & \text { sub } & \text { sektor } \\
\text { telekomunikasi } & \text { yang } & \text { mengalami } \\
\text { kerugian selama } & 2015-2019 & \\
\end{array}$ & (2) \\
\hline 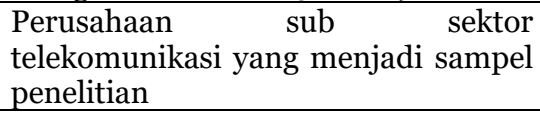 & 6 \\
\hline Tahun pengamatan penelitian & 5 \\
\hline Jumlah sampel & 30 \\
\hline
\end{tabular}

Daftar perusahaan yang digunakan dalam penelitian ini terdiri dari 6 perusahaan sub sektor telekomunikasi di Bursa Efek Indonesia 2015 - 2019 yang dapat dilihat pada table 2 berikut:

Tabel 3. Daftar Sampel Penelitian

\begin{tabular}{ccl}
\hline No & $\begin{array}{c}\text { Kode } \\
\text { Saham }\end{array}$ & \multicolumn{1}{c}{ Nama Emiten } \\
\hline 1 & BALI & Bali Towerindo Sentra Tbk. \\
\hline 2 & IBST & Inti Bangun Sejahtera Tbk. \\
\hline 3 & LINK & Link Net Tbk. \\
\hline 4 & TBIG & Tower Bersama Infrastructure Tbk. \\
\hline 5 & TLKM & Telkom Indonesia (Persero Tbk. \\
\hline 6 & TOWR & Sarana Menara Nusantara Tbk. \\
\hline
\end{tabular}

Sumber: Diolah Peneliti (2021)

\section{Uji Asumsi Klasik}

\section{Uji Asumsi Multikolinieritas}

Uji multikolinearitas digunakan untuk mengetahui apakah model regresi terdapat korelasi antar-variabel independen (Santoso, 2019).

Tabel 4. Hasil Uji Multikolinieritas ROA GROWTH

\begin{tabular}{ccc}
\hline \hline ROA & 1.000000 & -0.222458 \\
GROWTH & -0.222458 & 1.000000
\end{tabular}

Sumber: Eviews 9, diolah peneliti (2021)

Gejala multikolinieritas tidak terjadi apabila jika nilai korelasi antar semua variabel bebas yang diuji kurang 0,9 (Sarwono, 2016).

Dari hasil analisis, nilai korelasi antar semua variabel bebas yang diuji adalah sebesar -0,22458 atau lebih kecil dari 0,90 sehingga tidak terjadi multikolinieritas.

\section{Uji Asumsi Autokorelasi}

Uji autokorelasi digunakan untuk mengetahui apakah dalam sebuah model regresi linier terdapat korelasi antara kesalahan penganggu pada periode $t$ dengan kesalahan pada periode $\mathrm{t}-1$ (sebelumnya) (Santoso, 2019).

Tabel 5. Hasil Uji Autokorelasi

Breusch-Godfrey Serial Correlation LM Test:

\begin{tabular}{llll}
\hline \hline F-statistic & 1.264787 & Prob. $\mathrm{F}(2,25)$ & 0.2997 \\
Obs*R-squared & 2.756571 & Prob. Chi-Square(2) & 0.2520 \\
\hline \hline
\end{tabular}

Sumber: Eviews 9, diolah peneliti (2021)

Menurut Sarwono (2016), jika p-value lebih kecil dari o,05 maka tidak terjadi korelasi serial pada sebaran data. Dari hasil pengolahan data di atas didapat nilai Prob. Chi-Square (2) sebesar 0,2520 atau lebih dari 0,05 sehingga tidak terjadi adanya gejala autokorelasi.

\section{Uji Asumsi Heterokedastisitas}

Uji Heterokedastisitas digunakan untuk mengetahui pada sebuah model regresi terjadi ketidaksamaan varians residual dari satu pengamatan ke 
pengamatan yang lain (Santoso, 2019). Model regresi yang baik tidak terjadi gejala heterokedastisitas.

Tabel 6. Hasil Uji Heterokedastitisitas Heteroskedasticity Test: White

\begin{tabular}{llll}
\hline \hline F-statistic & 1.409015 & Prob. $F(5,24)$ & 0.2566 \\
Obs ${ }^{\star}$-squared & 6.807915 & Prob. Chi-Square(5) & 0.2353 \\
Scaled explained SS & 5.959401 & Prob. Chi-Square(5) & 0.3102
\end{tabular}

Sumber: Eviews 9, diolah peneliti (2021)

Menurut Sarwono (2016), jika pvalue lebih kecil dari 0,05 maka tidak terjadi gejala heterokedastisitas. Dari hasil pengolahan data di atas didapat nilai Prob. Chi-Square (5) sebesar 0,3102 atau lebih dari 0,05 sehingga tidak terjadi adanya gejala heterokedastisitas.

\section{Uji Asumsi Normalitas}

Uji normalitas digunakan untuk mengetahui dalam sebuah model regresi, nilai residu dari regresi mempunyai distribusi yang normal (Santoso, 2019).

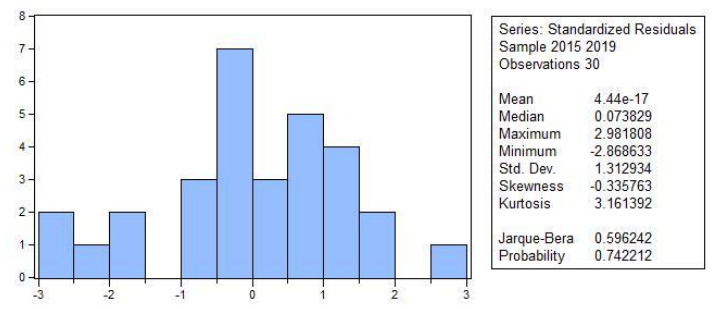

Gambar 2. Hasil Uji Normalitas Sumber: Eviews 9, diolah peneliti (2021)

Menurut Sarwono (2016), jika p-value lebih kecil dari 0,05 maka data berdistribusi normal. Dari hasil pengolahan data di atas didapat nilai Probability sebesar 0,7422 atau lebih dari 0,05 sehingga data berdistribusi normal.

\section{Analisis Regresi Linear Berganda}

Tabel 7. Hasil Analisis Regresi

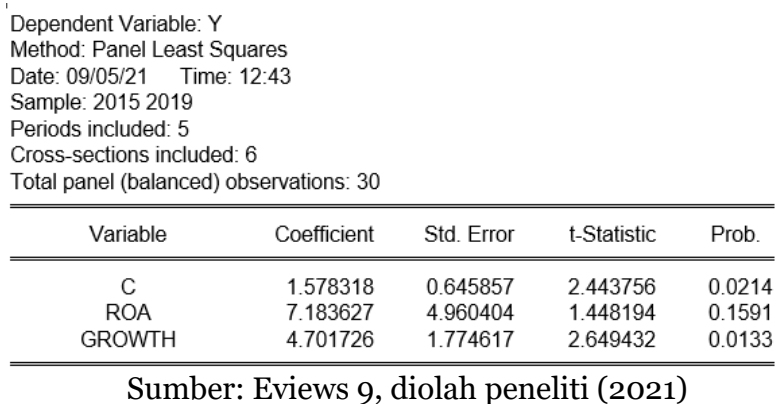

Sumber: Eviews 9, diolah peneliti (2021)

Dari hasil perhitungan diatas, maka persamaan regresi linier berganda sebagai berikut :

$Y=\alpha+\beta_{1} X_{1}+\beta_{2} X_{2}+e$
$Y=1.5783+7.1836$ ROA +4.717 growth $+e$

Hasil perhitungan statistik menunjukan bahwa variabel yang mempunyai parameter koefisien bertanda positif. Secara matematis tanda positif berarti setiap perubahan salah satu variabel bebas akan mengakibatkan perubahan variabel tidak bebas dengan arah yang berhubungan apabila variabel lainnya dianggap konstan. Sehingga dari persamaan diatas dapat dijelaskan sebagai berikut :

1. Konstan $\alpha$ sebesar 1.5783 artinya jika variabel ROA dan growth masingmasing memiliki nilai konstan (tetap), maka kenaikan 1 satuan akan menambah nilai perusahaan sub sektor telekomunikasi Bursa Efek Indonesia sebesar 1.5783 .

2. Koefisien regresi Return On Assets $\left(\mathrm{X}_{1}\right)$ sebesar 7.183627 menunjukan bahwa ketika ROA $\left(\mathrm{X}_{1}\right)$ meningkat sebesar 1 satuan, maka akan menambah nilai perusahaan sebesar 7.183627. Dengan anggapan variabel bebas lainnya konstan.

3. Koefisien regresi Growth $\left(\mathrm{X}_{2}\right)$ sebesar 4.7172 menunjukan bahwa ketika Growth $\left(\mathrm{X}_{2}\right)$ meningkat sebesar 1 satuan, maka akan menambah nilai 
perusahaan sebesar 4.7172. Dengan anggapan variabel bebas lainnya konstan.

\section{Uji Hipotesis}

\section{Uji F (Simultan)}

Digunakan untuk mengetahui pengaruh dari semua variabel bebas terhadap variabel terikat secara simultan atau bersama.

Tabel 8. Hasil analisis uji $\mathrm{f}$

\begin{tabular}{lrll}
\hline \hline R-squared & 0.224036 & Mean dependent var & 3.013937 \\
Adjusted R-squared & 0.166557 & S.D. dependent var & 1.490467 \\
S.E. of regression & 1.360693 & Akaike info criterion & 3.548505 \\
Sum squared resid & 49.99011 & Schwarz criterion & 3.688625 \\
Log likelihood & -50.22757 & Hannan-Quinn criter. & 3.593330 \\
F-statistic & 3.897718 & Durbin-Watson stat & 1.382722 \\
Prob(F-statistic) & 0.032573 & & \\
\hline \hline
\end{tabular}

Sumber: Eviews 9, diolah peneliti (2021)

Menentukan level of signifikan (a) dengan rumus $\mathrm{Df}=\mathrm{k} ; \mathrm{n}-\mathrm{k}$ dimana tarif signifikan 0,05 dengan derajat kebebasan (df) 2:28, sehingga Ftabel $=3,34$.

Dari hasil pengolahan data menggambarkan Eviews 9, dapat diketahui bahwa Fhitung sebesar 3.89. Sehingga bisa ditarik kesimpulan bahwa nilai Fhitung (3.89) > Ftabel (3,34) sehingga Ho ditolak dan $\mathrm{H} 1$ diterima. Hal ini berarti variabel ROA $\left(\mathrm{X}_{1}\right)$, dan GROWTH $\left(\mathrm{X}_{2}\right)$ secara bersama-sama mempunyai pengaruh simultan terhadap nilai perusahaan $(\mathrm{Y})$ perusahaan sub sektor telekomunikasi.

\section{Uji t (Parsial)}

Uji $t$ digunakan untuk menguji pengaruh variabel-variabel bebas secara parsial terhadap variabel terikat dengan pengujian secara mandiri.

Tabel 9. Hasil Analisis Uji T

\begin{tabular}{ccccc}
\hline \hline Variable & Coefficient & Std. Error & t-Statistic & Prob. \\
\hline \hline C & 1.578318 & 0.645857 & 2.443756 & 0.0214 \\
ROA & 7.183627 & 4.960404 & 1.448194 & 0.1591 \\
GROWTH & 4.701726 & 1.774617 & 2.649432 & 0.0133 \\
\hline \hline
\end{tabular}

Sumber: Eviews 9, diolah peneliti (2021)

Menentukan level of significant ( $\alpha$ ) dengan rumus $\mathrm{Df}=\mathrm{n}-\mathrm{k}-1$, dimana taraf signifikan 0,$05 ; 2=0,025$ (uji dua sisi) dengan derajat kebebasan (df) 27, sehingga diperoleh tabel $=2.05183$.

\section{Uji Parsial Variabel ROA}

Berdasakan kurva diatas menunjukan bahwa nilai - $t_{\text {tabel }}(-2.05183) \leq$ thitung $(1.448194) \leq t_{\text {tabel }}(2.05183)$, maka $\mathrm{H}_{\mathrm{o}}$ diterima dan $\mathrm{H}_{1}$ ditolak, berarti variable ROA $\left(\mathrm{X}_{1}\right)$ secara parsial tidak memiliki pengaruh terhadap Nilai Perusahaan (Y) pada perusahaan sub sektor telekomunikasi.

\section{Uji Parsial Variabel Growth}

Berdasakan kurva diatas menunjukan bahwa nilai -ttabel $(-2.05183) \geq$ tabel (2.05183) $\geq$ thitung (2.649432), maka $\mathrm{H}_{\mathrm{o}}$ ditolak dan $\mathrm{H}_{1}$ diterima, berarti variable growth $\left(\mathrm{X}_{2}\right)$ secara parsial memiliki pengaruh terhadap Nilai Perusahaan $(\mathrm{Y})$ pada perusahaan sub sektor telekomunikasi.

\section{Koefisien Determinasi}

\begin{tabular}{lrll}
\multicolumn{4}{c}{ Gambar 10. Hasil Analisis Regresi } \\
\hline \hline R-squared & 0.224036 & Mean dependent var & 3.013937 \\
Adjusted R-squared & 0.166557 & S.D. dependent var & 1.490467 \\
S.E. of regression & 1.360693 & Akaike info criterion & 3.548505 \\
Sum squared resid & 49.99011 & Schwarz criterion & 3.688625 \\
Log likelihood & -50.22757 & Hannan-Quinn criter. & 3.593330 \\
F-statistic & 3.897718 & Durbin-Watson stat & 1.382722 \\
Prob(F-statistic) & 0.032573 & & \\
\hline \hline
\end{tabular}

Sumber: Eviews 9, diolah peneliti (2021)

Nilai koefisien determinasi atau $\mathrm{R}^{2}$ digunakan untuk mengukur seberapa besar persentase variabel bebas yang digunakan dalam model dapat mempengaruhi variabel terikat $(\mathrm{Y})$ yaitu Nilai Perusahaan. Dari hasil analisis linier berganda diperoleh nilai $\mathrm{R}^{2}=0,1666$ yang berarti bahwa sebesar $16,66 \%$ nilai 
perusahaan dapat dipengaruhi oleh variabel ROA $\left(\mathrm{X}_{1}\right)$ dan GROWTH $\left(\mathrm{X}_{2}\right)$. Sedangkan sisanya $83,34 \%$ dipengaruhi oleh variabel lain yang tidak dimasukan dalam model penelitian ini.

\section{KESIMPULAN}

Berdasarkan hasil penelitian dan pembahasan maka dapat ditarik kesimpulan sebagai berikut:

1. Variabel ROA $\left(\mathrm{X}_{1}\right)$ dan GROWTH $\left(\mathrm{X}_{2}\right)$ secara bersama (simultan) mempunyai pengaruh terhadap nilai perusahaan (Y) perusahaan sub sektor telekomunikasi yang tergabung di BEI.

2. Hasil analisis pengujian secara parsial dapat ditarik kesimpulan sebagai berikut:

a. Return On Assets (ROA) tidak berpengaruh dan signifikan terhadap nilai perusahaan pada perusahaan sub sektor telekomunikasi yang tergabung di BEI.

b. Growth berpengaruh positif serta signifikan terhadap nilai perusahaan pada perusahaan sub sektor telekomunikasi yang terdaftar di BEI.

\section{SARAN}

1. Bagi calon investor yang akan berinvestasi pada perusahaan sub sector telekomunikasi dapat mempertimbangkan aspek kedua variabel ROA dan growth, namun lebih baik mengandalkan growth karena memiliki hasil pengaruh positif serta signifikan terhadap Nilai perusahaan.

2. Bagi peneliti selanjutnya, disarankan untuk melakukan penelitian lebih lanjut tentang rasio keuangan yang lain maupun variabel eksternal lainnya seperti inflasi, tingkat suku bunga, dan lain-lain.

3. Bagi peneliti selanjutnya, sebaiknya menambah periode penelitian yang akan digunakan, sehingga akan mampu diperoleh hasil yang lebih baik mengenai nilai perusahaan di BEI.

\section{DAFTAR PUSTAKA}

Hardiansyah, A., Soehardi, S., \& Rony, Z. T. (2019). PENGARUH DISIPLIN KERJA, MOTIVASI KERJA DAN KOMPENSASI TERHADAP KINERJA PEGAWAI BANK OCBC NISP BAGIAN RECORD MANAGEMENT DAN PARTNERSHIP OPERATION. Jurnal Ilmiah Manajemen Ubhara, 1(2), 147-161.

https://doi.org/http://dx.doi.org/10. 31599/jmu.v1i2.644

Hery, H. (n.d.). Analisis Laporan Keuangan: Integrated and Comprehensice Edition (PT Grasind).

Husna, A., \& Satria, I. (2019). Effects of Return on Asset, Debt To Asset Ratio, Current Ratio, Firm Size, and Dividend Payout Ratio on Firm Value. International Journal of Economics and Financial Issues, 9(5), 50-54. https://doi.org/10.32479/ijefi.8595

Meidiawati, K., \& Mildawati, T. (2016). Pengaruh Size, Growth, Profitabilitas, Struktur Modal, Kebijakan Dividen Terhadap Nilai Perusahaan. Jurnal Ilmu Dan Riset Akuntansi, 5(2), 1-16. Nanda Perwira, A. A. G. A., \& Wiksuana, I. G. B. (2018). Pengaruh Profitabilitas Dan Pertumbuhan Aset Terhadap Kebijakan Dividen Dan Nilai Perusahaan. E-Jurnal Manajemen Universitas Udayana, 7(7), 3767. https://doi.org/10.24843/ejmunud.2 018.v07.io7.p12

Oktrima, B. (2017). PENGARUH PROFITABILITAS, LIKUIDITAS, 
DAN STRUKTUR MODAL TERHADAP NILAI PERUSAHAAN (Studi Empiris: PT. Mayora Indah, Tbk. Tahun 2011 - 2015). 1(1), 98107.

Paminto, A., Setyadi, D., \& Sinaga, J. (2016). The Effect of Capital Structure , Firm Growth and Dividend Policy on Profitability and Firm Value of the Oil Palm Plantation Companies in Indonesia. European Journal of Business and Management, 8(33), 123-134.

https://core.ac.uk/download/pdf/23 4627620.pdf

Prihadi, T. (2019). Analisis Laporan Keungan: Konsep \& Aplikasi. PT Gramedia Pustaka Utama.

Putranto, P., \& Kurniawan, E. (2018). Effect of managerial ownership and profitability in firm value. European Journal of Business and Management, 10(25), 96-104. https://iiste.org/Journals/index.php /EJBM/article/view/44461

Refiani, S. M. (2021). Pengaruh Struktur Modal Dan Profitabilitas Terhadap Nilai Perusahaan Pada Perusahaan Sub Sektor Tekstil Dan Garmen Yang Terdaftar Di Bursa Efek Indonesia Periode 2015-2019. 1-11.

Sanjaya, R., \& Henviani, H. (2020). Factors That Influence On The Price To Book Value Of The Company In Indonesia Stock Exchange. Riset, 2(2), 361-372. https://doi.org/10.35212/riset.v2i2.5 8

Santoso, S. (2019). Mahir Statistik Parametrik. PT Elex Media Komputindo.

Sarwono, J. (2016). Prosedur-Prosedur Analisis Populer Aplikasi Riset Skripsi dan Tesis Dengan Eviews. Penerbit Gava Media.

Sugeng, B. (2017). Manajemen Keuangan Fundamental. Penerbit Deepublish.
SUSANTI, A., WAFIROTIN, K. Z., \& HARTONO, A. (2019). Pengaruh Good Corporate Governance, Profitabilitas, Dan Ukuran Perusahaan Terhadap Nilai Perusahaan Manufaktur Yang Terdaftar Di Bei Periode Tahun 20112016. ISOQUANT: Jurnal Ekonomi, Manajemen Dan Akuntansi, 3(1), 11. https://doi.org/10.24269/iso.v3i1.23 6

Syahrial, M. S., Yuliansyah, Y., \& Sudrajat, S. (2020). The Effect of Company Growth on Firm Value with Debt Policy as Moderation in Service Sector Industries. International Journal for Innovation Education and Research, $8(8)$, 445-453. https://doi.org/10.31686/ijier.vol8.is s8.2538

Ukhriyawati, C. F., \& Putri, R. W. (2016). Pengaruh Likuiditas, Leverage dan Profitabilitas terhadap Nilai Perusahaan pada Perusahaan Telekomunikasi yang Terdaftar di Bursa Efek Indonesia Tahun 20122014. Jurnal Bening, 3(1), 52-73.

Wastam Wahyu Hidayat, Soehardi, \& Husadha, C. (2021). Pengaruh Corporate Governance Terhadap Manajemen Pajak. Jurnal Manajemen Strategi Dan Aplikasi Bisnis, 4(2), 429-440. https://doi.org/http://www.ejournal. imperiuminstitute.org/index.php/JM $\mathrm{SAB} /$ article/view/323

Yuslirizal, A. (2017). Pengaruh Kepemilikan Manajerial, Kepemilikan Institusional, Growth, Likuiditas Dan Size Terhadap Nilai Perusahaan Pada Industri Tekstil Dan Garmen Di Bursa Efek Indonesia. Katalogis, 5(3), 116126.

(Hery, n.d.; Husna \& Satria, 2019; Meidiawati \& Mildawati, 2016; Nanda Perwira \& Wiksuana, 2018; 
Oktrima, 2017; Paminto et al., 2016; Prihadi, 2019; Putranto \& Kurniawan, 2018; Refiani, 2021; Sanjaya \& Henviani, 2020; Santoso, 2019; Sarwono, 2016; Sugeng, 2017;
SUSANTI et al., 2019; Syahrial et al., 2020; Ukhriyawati \& Putri, 2016; Yuslirizal, 2017) 